\title{
Juridical Aspects Of Complementary Traditional Medicine In Indonesia
}

\author{
Bambang Siswanto $^{1 *}$, Sri Setiawati ${ }^{2}$, Ontran Sumantri Riyanto ${ }^{3}$ \\ ${ }^{1,2}$ Faculty of Law, University of 17 August 1945 Semarang, Indonesia \\ ${ }^{3}$ STIKES Bethesda Yakkum Yogyakarta, Indonesia \\ ${ }^{*}$ Corresponding author: \\ Email: bambang-siswanto@,untagsmg.ac.id
}

\begin{abstract}
.
Alternative, complementary medicine is non-conventional medicine aimed at improving public health status, including promotive, curative, preventive, and rehabilitative efforts obtained through structured education with high quality, safety, and effectiveness based on biomedical science, which has not been accepted in conventional medicine. In several hospitals in Indonesia, this complementary medicine has begun to be applied as supportive therapy or replacement therapy for patients who refuse traditional treatment methods. This complementary therapy can also be carried out at the patient's request or with the referral of other doctors. The approach method used in this study, namely normative juridical, is a method of legal research conducted on library materials or secondary data using deductive thinking methods based on truth criteria. Coherent. There is also a complementary therapy called holistic medicine, which is because the form of therapy can affect individuals. The limitations of conventional medicine are one of the reasons why complementary and alternative therapies are an option in treating/healthy Indonesian people. The development of complementary and alternative therapies must be the responsibility of health workers, especially nurses. Legality for complementary and integrated health services must have a Traditional Health Worker Registration Certificate (STRTKT) and a Traditional Health Worker Practice License (SIPTKT).
\end{abstract}

Keywords: Therapy, traditional complementary

\section{INTRODUCTION}

Health is a human right and one of the elements of welfare that must be realized by the ideals of the Indonesian nation as referred to in the Pancasila and the 1945 Constitution of the Republic of Indonesia. Health efforts are every activity and/or a series of activities carried out in an integrated manner, integrated and sustainable to maintain and improve the degree of public health in the form of disease prevention, health improvement, disease treatment, and health restoration by the government and/or the community [1].

Community efforts to obtain health for themselves are preventive and curative. Preventive efforts include running a healthy lifestyle [2]. Curative efforts to carry out treatment, both medical and non-medical. Non-medical treatment includes traditional medicine[3], which consists of empirical traditional health services, traditional complementary; and traditional integration [4]. 
According to the Big Indonesian Dictionary (KBBI), treatment or therapy is an effort to restore the health of people who are sick, treat disease, or treat disease. Complementary is complementary[4], or perfect. According to WHO (World Health Organization), complementary medicine is non-conventional medicine that does not come from the country concerned. Complementary therapy is a way of dealing with a disease that is carried out as a supporter [5]or companion to conventional medical treatment or as a treatment option other than conventional medical treatment. Jamu is an Indonesian product that is categorized as complementary medicine in Singapore, but in Indonesia itself, jamu is categorized as traditional medicine [6].

Traditional and complementary medicine in Indonesia are in great demand and openly accepted by the public [7]. This is influenced by many factors, including cultural, traditional, religious, social, economic factors, a saturation of medical treatment, education, and knowledge about the disease. The community considers traditional or complementary medicine as an "effort" step and will easily accept it if it does not work compared to medical efforts. Problems occur if the treatment does not work as expected, the costs incurred are large, patient anxiety will occur which often leads to legal problems [8].

The government has regulated this traditional and complementary medicine in Government Regulation No. 103 of 2014 concerning Traditional Health. However, many treatment providers and patients do not understand this.

\section{METHODS}

The approach method used in this research is normative juridical, a method of legal research conducted on library materials or secondary data using deductive thinking methods based on coherent truth criteria. The collecting of legal materials uses a systematic method, namely containing materials for laws and regulations concerning the regulation of health law, traditional health services, legal concepts, and existing legal theories. Its relevance to traditional health services. The legal material analysis technique used is a description technique.

\section{RESULT AND DISCUSSION}

\section{A. Complementary Medicine}

Traditional medicine is a treatment that has been used since ancient times and passed down from generation to generation in a country. According to the Regulation of the Minister of Health, the definition of traditional-alternative complementary medicine or often referred to as CAM (Complementary Alternative Medicine) is nonconventional treatment aimed at improving the health status of the community, including promotive, preventive, curative, and rehabilitative efforts obtained through structured education with quality, safety, and high effectiveness based on biomedical science.

Complementary medicine is a traditional medicine that has been recognized and can be used as a companion to conventional/medical therapy. Alternative medicine is a 
type of treatment that is not carried out by paramedics/doctors in general, but by an expert or practitioner who masters his/her expertise through other/non-medical education[9].

Traditional health services are divided into traditional health services that use skills and traditional health services using herbs. These traditional health services are fostered and supervised by the Government so that their benefits and safety can be accounted for and do not conflict with religious norms. Further provisions regarding the procedures and types of traditional health services, whether using skills or ingredients, shall be regulated by a Government Regulation.[8]

Currently, complementary therapies in Indonesia are well recognized and widely used by the community to meet their health needs[10]. The use of complementary therapies is generally preferred to treat a disease. In health services, complementary therapy is an option for the community in seeking solutions to health problems. People typically choose complementary therapy methods because they are easy to obtain and relatively inexpensive compared to modern medicine.

Complementary therapeutic health services that use tools and technology must obtain permission from the authorized health institution. The use of these tools and technology must be accountable for their benefits and safety and not conflict with the religious and cultural norms of the community. In addition, every party who will carry out complementary therapy services must register with the Head of the local Regency / City Health Office to obtain a Traditional Medicine Registered Letter (STPT) so that traditional health services are under government supervision. Therefore, traditional health services cannot stand alone. Instead, it is supported by the provisions governing traditional health services' implementation.

This Government Regulation divides traditional health services into empirical, complementary, and integrated traditional health services. Empirical traditional health care is the application of traditional health services whose benefits and safety are empirically proven. Complimentary Traditional Health Services is the application of traditional health that utilizes biomedical and biocultural sciences in its explanation and its benefits and safety are scientifically proven. Integrated Traditional Health Services is a form of health service that combines conventional health services with complementary traditional health services[11].

Complementary Traditional Health Services may use one method of treatment/treatment or a combination of methods of treatment/treatment in a single unit of Complementary Traditional Health Services as referred to in paragraph (1) carried out in Traditional Health Service Facilities. Complementary Traditional Health Services that meet certain criteria can be integrated into the Health Service Facility. Certain criteria as referred to in paragraph (4) include:

a. Follow scientific principles;

b. Does not endanger the health of the patient/client;

c. Continue to pay attention to the best interests of patients/clients; 
d. Has promotive, preventive, curative, rehabilitative potential, and improves the quality of life of patients/clients physically, mentally, and socially; and

e. Performed by traditional health workers.

Complementary Traditional Health Services are carried out using treatment/care using skills; and/or potions. Complementary Traditional Health Services that use the skills as referred to in Article 11 letter a is carried out using: manual techniques, energy therapy; and/or thought therapy.

Complementary Traditional Health Services that use ingredients as referred to in Article 11 letter $\mathrm{b}$ are carried out using ingredients derived from a. plant; $b$. animal; $\mathrm{c}$. mineral; and/or d. sarian (galenik) preparations or mixtures of ingredients. In the use of sarian (gatenik) preparations or mixtures of ingredients as referred to in paragraph (21 letter d), Indonesian ingredients are prioritized.

\section{B. Types of complementary therapy in Indonesia}

\section{Complementary Medicine}

This type of action is based on biomedical science and has been accepted by conventional medicine and is carried out by doctors, dentists, and other health workers who have a certificate of competence and special expertise in the field of complementary medicine[12]. This regulation is regulated through the Regulation of the Minister of Health of the Republic of Indonesia Number 1109/MENKES/per/2007 concerning the Implementation of Complementary-Alternative Medicine in Health Service Facilities.

Doctors act as leaders or who are responsible for complementary actions given to clients. The positions of other health workers who play a role in this therapy are nurses, midwives, physiotherapists who have competency certificates and are recognized by professional organizations and institutions authorized in the competency test. In contrast to complementary nursing actions, medical complementary actions are carried out in health service facilities: Hospitals, groups, and individual practices and must have a doctor in charge. Nurses can perform complementary medical actions by becoming a doctor's assistant in carrying out these complementary actions.

The conditions that must be met to carry out complementary medical actions at the health service facility include:

a. Have a certificate of education in health workers (doctor, dentist, nurse, etc.)

b. Get recommendations from professional organizations

c. Have certification and have passed the competency test for certain skills in the field of complementary medicine

d. Have SBR-TPKA (Proof of Registration of Complementary-Alternative Medical Personnel)

e. Have ST-TPKA (Assignment Letter for Complementary-Alternative Medicine)

f. Have SIK-TPKA (Complementary-Alternative Medical Work Permit) 
Meanwhile, the determination of complementary actions that can be carried out in health service facilities is determined by the Minister of Health. In Indonesia, there are 3 types of complementary medical treatment techniques that have been integrated into conventional medical services, namely:

a. Medical acupuncture is an alternative medicine method that has been based on biomedical science and is in synergy with conventional medicine. It is called alternative medicine because acupuncture is a traditional Chinese medicine used in Indonesia. Acupuncture is useful in treating certain health conditions and also as an analgesic (pain reliever).

b. Hyperbaric therapy, which is a method of therapy where the patient is in a room and is given pure oxygen pressure. This therapy is often used in patients with gangrene to prevent amputation.

c. Medical herbal therapy, namely therapy using natural medicines, either in the form of standardized herbs in research service activities or the form of phytopharmaca.

Therapy using medical herbs is further regulated by the Decree of the Minister of Health of the Republic of Indonesia Number 121/MENKES/SK/II/2008 concerning Standards for Herbal Medical Services. Several requirements must be met, namely:

a. Has competency certification in the herbal field and has received authority from the Indonesian Doctors Association of Eastern Traditional Health Developers seminar organization

b. Manpower standards are doctors and or dentists who already have competence.

c. The materials used must be standardized (finished drugs) but if you make your own, the implementing doctor must be accompanied by a pharmacist assistant.

d. Hospitals that can provide herbal medical services must obtain permission from the Ministry of Health of the Republic of Indonesia.

\section{Alternative Traditional Complementary}

By the Regulation of the Minister of Health, the definition of alternative traditional complementary medicine is non-conventional treatment aimed at improving the health status of the community including promotive, preventive, curative, and rehabilitative efforts obtained through structured education with high quality, safety, and effectiveness based on biomedical science but has not been accepted. in conventional medicine. In its implementation, it must be synergized and integrated with conventional medical services with doctors, dentists, and other health workers having education in the field of alternative traditional complementary medicine.

\section{Complementary and Alternative Medicine: What's the Difference?}

It is important to understand the difference between complementary medicine and alternative medicine - the two approaches are often confused but are, in fact, different. 
Complementary medicine refers to healing practices and products that work in conjunction with traditional medicine. For example, cancer patients receiving chemotherapy may also experience acupuncture to help manage chemotherapy side effects such as nausea and vomiting[13]. Alternative medicine is different because it is not used as a compliment, but as a substitute for traditional therapy. An example is a cancer patient who forgoes recommended chemotherapy and instead chooses to treat the disease with certain dietary changes[14].

There is a third category that also often gets equated with conventional and alternative medicine - integrative medicine. Integrative medicine draws from both complementary and alternative medicine and combines these with traditional Western therapies.

The National Center for Complementary and Alternative Medicine (NCCAM) recently surveyed Americans on the use of complementary and alternative medicine. The survey, which collected information from more than 20,000 adults and nearly 10,000 children, found that about 40 percent of adults and 12 percent of children used some form of complementary and alternative medicine.

Women, people ages 40 to 60 , and adults with higher levels of education and income tend to use complementary and alternative therapies more frequently. There has been a considerable increase in the number of people using common forms of complementary and alternative medicine, such as yoga, meditation, acupuncture, andmassage therapy[12].

\section{Rights and Duties of Complementary Traditional Health Workers}

Traditional health workers in providing Complementary Traditional Health Services have the right:

a. Obtain legal protection as long as they carry out their duties by professional standards, service standards, and standard operating procedures;

b. Obtain complete and honest information from patients/clients or their families; and

c. Receive a service fee.

Traditional health workers in providing complementary traditional health services have the following obligations:

a. Provide Complementary Traditional Health Services by professional standards, service standards, and standard operating procedures, as well as patient/client needs;

b. Refer patients/clients in life-threatening and emergencies or other conditions that cannot be handled;

c. Keep everything he knows about the patient/client; and

d. Increase knowledge and follow the development of complementary traditional health sciences. 


\section{E. Rights and Obligations of Patients/Clients of Complementary Traditional Health Services}

Patients/clients in receiving Complementary Traditional Health Services have the right:
a. Get a complete explanation of the services to be performed;
b. Ask the opinion of other traditional health workers;
c. Get services according to need;
d. Rejecting complementary traditional service measures; and
e. Get the contents of the health record.

Patients/clients in receiving complimentary traditional health services have the following obligations:

a. Provide complete and honest information about their health problems;

b. Comply with the advice and instructions of traditional health workers;

c. Comply with applicable regulations in health care facilitiestraditional; and

d. Provide compensation for services received.

\section{CONCLUSION}

Complementary therapy deals with the disease that is carried out as a support to conventional medical treatment or as a treatment option other than traditional medical treatment. The development of complementary or alternative therapies has been extensive, including people involved in providing therapy because many health professionals and therapists other than general practitioners are interested in complementary therapy. This can increase the development of science through research that can facilitate complementary therapies to become more accountable. The result of complementary and alternative therapies must be the responsibility of health workers, especially nurses. Legality for complementary and integrated health services must have a Traditional Health Worker Registration Certificate (STRTKT) and a Traditional Health Worker Practice License (SIPTKT).

\section{REFERENCES}

[1] RISKESDAS, "Riset Kesehatan Dasar 2018," Kementrian Kesehatan Republik Indonesia, 2018.

[2] A. Sriatmi, S. Jati, and A. Rahmawati, "Analisis Implementasi Pengintegrasian Pelayanan Kesehatan Tradisional Di Puskesmas Halmahera Kota Semarang," Jurnal Kesehatan Masyarakat (e-Journal), vol. 4, no. 1, 2016.

[3] I. Heriani and M. Munajah, "Aspek Legalitas Terhadap Pelayanan Kesehatan Tradisional Di Indonesia," Al-Adl: Jurnal Hukum, vol. 11, no. 2, 2020, doi: 10.31602/al-adl.v11i2.2452.

[4] L. Widowati, O. D. Sampurno, H. Siswoyo, R. Sasanti, N. Nurhayati, and D. Delima, "Kajian Kebijakan Pemanfaatan Obat Tradisional Di Fasilitas Pelayanan Kesehatan Pada Era Jaminan Kesehatan Nasional," Buletin Penelitian Sistem Kesehatan, vol. 23, no. 4, 2020, doi: 10.22435/hsr.v23i4.3379.

[5] N. P. Sumartini, D. Purnamawati, and N. K. Sumiati, "Pengetahuan Pasien Yang 
Menggunakan Terapi Komplementer Obat Tradisional Tentang Perawatan Hipertensi Di Puskesmas Pejeruk Tahun 2019," Bima Nursing Journal, vol. 1, no. 1, 2020, doi: 10.32807/bnj.v1i2.516.

[6] N. A. T. Utami and N. Alawiya, "Perlindungan Hukum Terhadap Pelayanan Kesehatan Tradisional di Indonesia," Volksgeist: Jurnal Ilmu Hukum dan Konstitusi, vol. 1, no. 1, 2018, doi: 10.24090/volksgeist.v1i1.1605.

[7] G. Gusmi, "Gambaran Karakteristik Pemanfaatan Pelayanan Kesehatan Tradisional," Jurnal Ilmiah Kesehatan, vol. 12, no. 1, 2020, doi: 10.37012/jik.v12i1.183.

[8] A. Riswandi, "Pengaruh Faktor Komunikasi, Sumber Daya, Disposisi dan Struktur Birokrasi dalam Implementasi Kebijakan Pelayanan Kesehatan Tradisional Integrasi Terhadap Penyelenggaraan Pelayanan Kesehatan Tradisional di Puskesmas," Gunahumas, vol. 3, no. 1, 2020, doi: 10.17509/ghm.v3i1.28403.

[9] W. Widyatuti, "Terapi Komplementer Dalam Keperawatan," Jurnal Keperawatan Indonesia, vol. 12, no. 1, 2008, doi: 10.7454/jki.v12i1.200.

[10] A. Purwadianto, S. Soetedjo, and R. Sjamsuhidajat, "Sikap Etik Dokter Terhadap Pelayanan Kesehatan Tradisional," Jurnal Etika Kedokteran Indonesia, vol. 3, no. 1, 2019, doi: 10.26880/jeki.v3i1.29.

[11] A. Wahyuni, L. Juwita, R. Rahmiwati, and R. Oktorina, "Pendidikan Kesehatan Tentang Hipertensi Dan Terapi Komplementer," Jurnal of Community Health Development, vol. 2, no. 2, 2021.

[12] D. L. Rohmawati and E. Prawoto, "Pemberdayaan masyarakat peduli hipertensi sebagai upaya penurunan tekanan darah melalui terapi komplementer," Journal of community health development, vol. 1, no. 1, 2020.

[13] H. Platini, S. Pebrianti, and K. K, "Penguatan Kapasitas Petugas Kesehatan Dalam Mengaplikasikan Terapi Komplementer Pasien Tuberkulosis Paru," Media Karya Kesehatan, vol. 1, no. 2, 2018, doi: 10.24198/mkk.v1i2.18634.

[14] Y. Saputra, "Survey Pengetahuan Masyarakat Tentang Terapi Komplementer," REAL in Nursing Journal (RNJ), vol. 4, no. 2, 2021. 